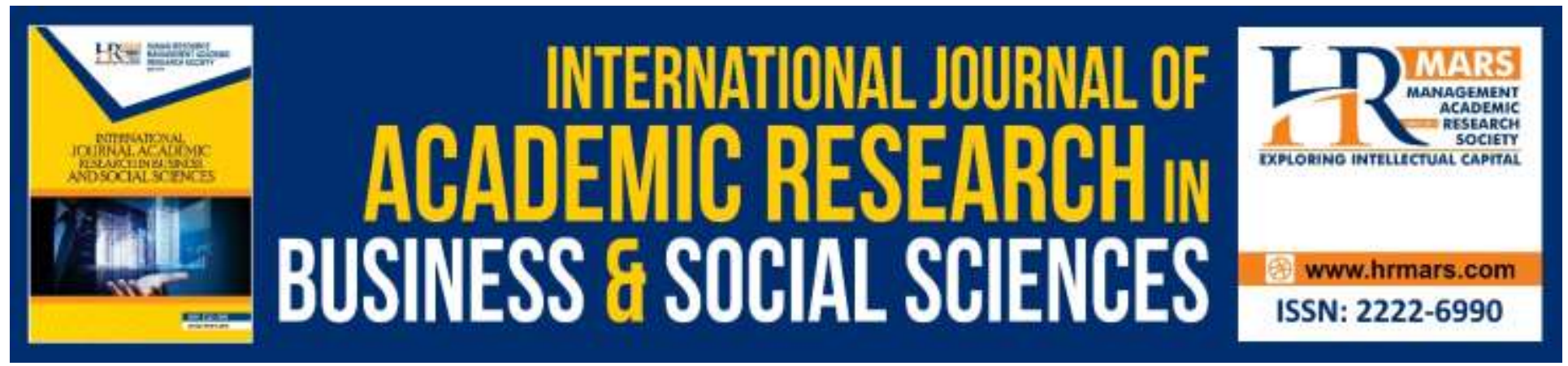

\title{
Validity and Reliability of Psychological Characteristics Questionnaire in Malaysian Male Talented Football Players
}

\author{
Khairul Sham Hanapiah, Ahmad Hashim \& Zulakbal Abd Karim
}

To Link this Article: http://dx.doi.org/10.6007/IJARBSS/v9-i11/6517

DOI: 10.6007/IJARBSS/v9-i11/6517

Received: 13 September 2019, Revised: 10 October 2019, Accepted: 30 October 2019

Published Online: 04 November 2019

In-Text Citation: (Hanapiah, Hashim \& Karim, 2019)

To Cite this Article: Hanapiah, K. S., Hashim, A., \& Karim, Z. A. (2019). Validity and Reliability of Psychological Characteristics Questionnaire in Malaysian Male Talented Football Players. International Journal of Academic Research in Business and Social Sciences, 9(11), 50-61.

Copyright: (C) 2019 The Author(s)

Published by Human Resource Management Academic Research Society (www.hrmars.com)

This article is published under the Creative Commons Attribution (CC BY 4.0) license. Anyone may reproduce, distribute, translate and create derivative works of this article (for both commercial and non-commercial purposes), subject to full attribution to the original publication and authors. The full terms of this license may be seen

at: http://creativecommons.org/licences/by/4.0/legalcode

\section{Vol. 9, No. 11, 2019, Pg. 50 - 61}

http://hrmars.com/index.php/pages/detail/IJARBSS

JOURNAL HOMEPAGE

Full Terms \& Conditions of access and use can be found at http://hrmars.com/index.php/pages/detail/publication-ethics 


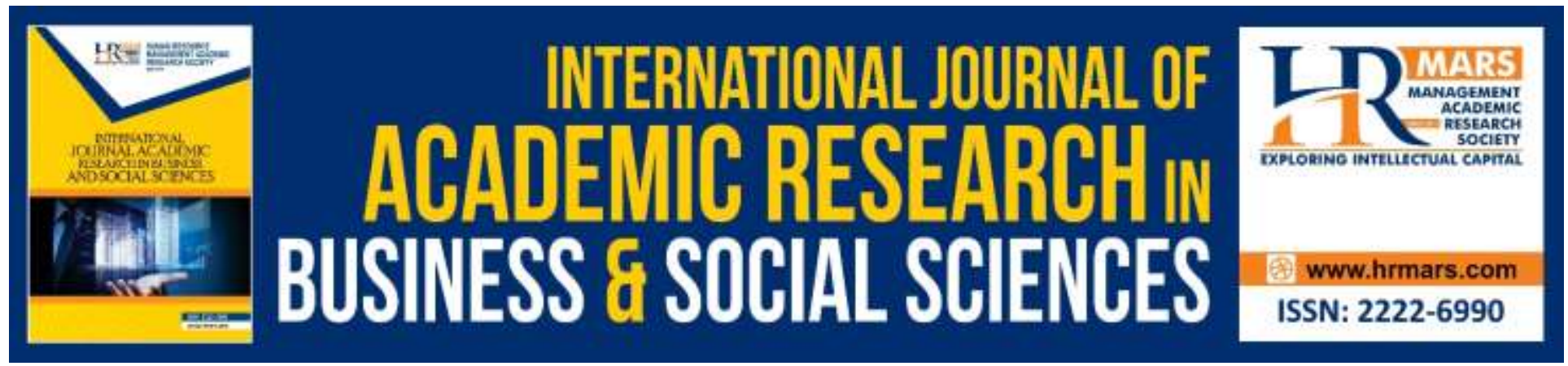

\title{
Validity and Reliability of Psychological Characteristics Questionnaire in Malaysian Male Talented Football Players
}

\author{
Khairul Sham Hanapiah, Ahmad Hashim \& Zulakbal Abd Karim \\ Faculty of Sports Science and Coaching, Sultan Idris Education University, Tanjong Malim, Perak, \\ Malaysia \\ Email: khairulsham@yahoo.com
}

\begin{abstract}
The main aim of this study is to obtain the validity and reliability of psychological characteristics questionnaire in Malaysian male talented football players aged 13 to 14 years old. Nine sub attributes are used to measure the attributes of psychological characteristics, which are anxiety control, mental preparation, team orientation, concentration, self-confidence, motivation, coping with adversity, peaking under pressure and coach ability. A total of 120 male football players aged 13 to 14 who underwent training under the Malaysia National Football Development Program were selected as study samples. Pearson correlation analysis were used to obtain validity of field experts. Cronbach's alpha analysis were used to obtain reliability coefficient of the psychological characteristics questionnaire. Factor analysis was used to obtain the construct validity of the questionnaire items. The factor analysis results showed 50 questionnaire items are valid from the overall 79 items constructed. The result of Pearson correlation analysis shows the value of field experts validity is $r=.92$. Cronbach's alpha analysis of questionnaire items obtained high reliability total value of $\alpha=.86$ and the internal consistency coefficient for each sub attributes are anxiety control $(\alpha=.83)$, mental preparation $(\alpha=.82)$, team orientation ( $\alpha=.84)$, concentration $(\alpha=.83)$, self-confidence $(\alpha=.84)$, motivation $(\alpha=.82)$, coping with adversity $(\alpha=.87)$, peaking under pressure $(\alpha=.86)$ and coach ability $(\alpha=.81)$. The attributes of psychological characteristics questionnaire are shown to be valid and reliable.
\end{abstract}

Keywords: Validity, Reliability, Psychological Characteristics, Anxiety Control, Mental Preparation, Team Orientation, Concentration, Self-Confidence, Motivation, Coping With Adversity, Peaking Under Pressure and Coach ability. 
INTERNATIONAL JOURNAL OF ACADEMIC RESEARCH IN BUSINESS AND SOCIAL SCIENCES

Vol. 9, No. 11, November, 2019, E-ISSN: 2222-6990 @ 2019 HRMARS

\section{Introduction}

Psychological characteristics, including personality traits and psychological skills, have been shown to be relevant predictors of football performance (Musculus \& Lobinger, 2018). In recent years, there have been increasing studies to identify specific personality traits or psychological profiles associated with sports performance (Durand-Bush \& Salmela, 2002; Jones et al., 2001; MacNamara \& Collins, 2012, 2015; McCarthy et al., 2010). Development of psychological characteristics in young players is like technique, tactics and physical condition, the result of systematic and logical training and must be integrated into the planning and organization of training sessions and matches. Personality traits were defined as a predisposition to behave in a certain way (Musculus \& Lobinger, 2018). Psychological skills were defined as athletes' ability to use learned psychological strategies (e.g., self-talk) to regulate and facilitate the enhancement of psychological characteristics (Dohme et al., 2017). Psychological characteristics were defined as predispositions that impact upon athlete development (e.g., self-confidence) (Dohme et al., 2017). In assessing the psychological characteristics, the personality trait and psychological skills are important to be assessed in the context of football players' performances.

According to Reilly, Williams, \& Richardson (2003), a preliminary studies in sports psychology investigated the personality traits category and psychological skills that distinguish between talented and less talented athletes. Personality traits are believed to be relatively stable over time and psychological skills are less stable, meaning that they can change according to the situation or context (Morris, 2000; Musculus \& Lobinger, 2018; Williams \& Reilly, 2000). According to Morris (2000), previous studies showed no evidence of association between sports performance and the specific personality characteristics. Furthermore, sports psychologists have studied the importance of changing personality characteristics in sport-specific by using state (as opposed to traits) or interactionist (based on personal and situational factors) approaches (Williams \& Reilly, 2000). Although this measurement tool is successful in distinguishing elite and sub-elite athletes, there is no strong indication that psychological characteristics can be used in football talent identification because these profiles change across different phases of player development.

Athlete's capacity (for example, better ability to cope with adversity) and willingness to perform a task are important indicators of relationship between personality characteristics and sports performance to achieve success in sports (Allen, Greenlees, \& Jones, 2013). There are two main issues of psychological characteristics that contribute to the highest performance. Firstly, which psychological characteristics are needed to achieve the highest performance? And secondly, how can these characteristics of be developed in young talents? (Elbe \& Wikman, 2017). Previous studies suggests that psychological characteristics of developing excellence equip aspiring elites with the necessary mental skills, attitudes, and emotions to cope with the inevitable challenges of the development pathway (MacNamara \& Collins, 2012). Overall, there is evidence that the most successful athletes at various levels of non-elite (juniors or seniors competing below national level), junior elite (junior national to junior international level), elite (senior international level) and super elite (gold medalist at Olympics or World Championships) have some of the psychological characteristics such as motivation, confidence and perceived control, mental toughness and resilience, cope with adversity, greater resistance to 'choking' (i.e. 
performing worse than expected in high-pressure situations and mental skills (e.g., goal-setting, anxiety control and decision-making) (Rees et al., 2016). According to Williams \& Reilly (2000), personality characteristics that associated with the performance of talented football players such as self-confidence, anxiety control, motivation and concentration can be refined through appropriate training.

The philosophy or DNA of Malaysian football through the National Football Development Program emphasized on the player's psychological characteristics development. A high-level young football players must not only be technically and tactically competence, but also need to be a person of high team spirit, mentally strong to overcome feelings of inferiority, tremendous drive and determination to win, mentally prepared to cope with stress, concentration throughout the game, confidence in difficult situations, desire and eagerness in matches and personality that in turn will result in performances on the pitch (Kementerian Belia dan Sukan Malaysia, 2014). In line with Malaysian football DNA, researchers have developed psychological characteristics questionnaire based on adaptations and modifications of the Athletic Coping Skills Inventory-28 (Smith, Schutz, Smoll, \& Ptacek, 1995) and the Psychological Skills Inventory for Sports (Mahoney et al., 1987). Anxiety control, mental preparation, team orientation, concentration, selfconfidence, motivation, coping with adversity, peaking under pressure and coach ability are important psychological characteristics for future career progression in football. The questionnaire refers to the way of talented football players doing self-assessment about the psychological readiness for learning/training and competition. The talented football players must be equipped with higher levels of psychological characteristics in order to achieve elite performance.

\section{Objective}

This study aims to obtain the validity and reliability of psychological characteristics questionnaire in Malaysian male talented football players aged 13 to 14 years old.

\section{Methodology}

This cross-sectional study is divided into three phases. The first phase started with the development of psychological characteristics questionnaire and obtaining validity of the field experts. Second phase is the determination of the reliability of the questionnaire items. While the third phase involves the measurement of construct validity of the questionnaire items. The population of this study is defined as male football players aged 13 to 14 years old who has been trained under the Malaysia National Football Development Program in 2018/2019 session. The researchers randomly selected 120 players after taking into consideration of absence or mortality factor (Konting, 2009) and the sample size of minimum 100 participants for factor analysis (Hashim, 2014).

In this study, the dependent variable is the football playing ability score. While independent variables are the scores of each sub attributes of anxiety control, mental preparation, team orientation, concentration, self-confidence, motivation, coping with adversity, peaking under pressure and coach ability. Table 1 shows the study variables. The researchers developed the psychological characteristics questionnaire by using the 5 points Likert scale $(1=$ 
never, 2 = rarely, 3 = sometimes, $4=$ often and 5 = always). Psychological characteristics questionnaire has 79 items at the initial stage of the study to measure nine sub attributes namely anxiety control, mental preparation, team orientation, concentration, self-confidence, motivation, coping with adversity, peaking under pressure and coachability. A total of 120 respondents were selected in this study to identify the validity and reliability of questionnaire items.

Table 1. Variables of Study

\begin{tabular}{|c|c|c|}
\hline Attribute & Sub Attribute & Indicator \\
\hline \multirow[t]{9}{*}{$\begin{array}{l}\text { Psychological } \\
\text { Characteristics }\end{array}$} & Anxiety Control & $\begin{array}{l}\text { - Deal with anxiety in practices and } \\
\text { games } \\
\text { - Worry free about performing and what } \\
\text { others will think }\end{array}$ \\
\hline & Mental Preparation & $\begin{array}{l}\text { - Mentally prepares for games } \\
\text { - Clearly has a game plan for performing } \\
\text { well }\end{array}$ \\
\hline & Team Orientation & $\begin{array}{l}\text { - Teamwork during practices and games } \\
\text { - Collaboration toward specific } \\
\text { performance goals and plans }\end{array}$ \\
\hline & Concentration & $\begin{array}{l}\text { - Easily distracted } \\
\text { - Able to focus on the task during } \\
\text { practices and games }\end{array}$ \\
\hline & Self-Confidence & $\begin{array}{l}\text { - Confidence to perform a task } \\
\text { - Confidence to compete against } \\
\text { opponents }\end{array}$ \\
\hline & Motivation & $\begin{array}{l}\text { - Consistently gives } 100 \% \text { during } \\
\text { practices and games } \\
\text { - Work hard to improve skills }\end{array}$ \\
\hline & Coping With Adversity & $\begin{array}{l}\text { - Remains positive and enthusiastic } \\
\text { - } \quad \text { Remains calm and controlled }\end{array}$ \\
\hline & Peaking Under Pressure & $\begin{array}{l}\text { - Deal with pressure situations } \\
\text { - } \quad \text { Performs well under pressure }\end{array}$ \\
\hline & Coachability & $\begin{array}{l}\text { - Open and learns from instruction } \\
\text { - Accepts constructive criticism }\end{array}$ \\
\hline
\end{tabular}

\section{Data Analysis Procedures}

Statistical Package for the Social Sciences (SPSS) 21.0 version software was used to analyses the data of psychological characteristics questionnaire. Pearson correlation analysis was used to obtain the validity of field experts based on the consensus of the three expert panels. Cronbach' alpha analysis was used to obtain the questionnaire's reliability and internal consistency 
coefficient questionnaire items. Factor analysis attempts to identify a small set of factors that represents the underlying relationships among a group of related variables (Pallant, 2010).

\section{Results}

Based on the suggested formula of Noah \& Ahmad (2005) for expert panel evaluation on 10 questionnaire items being valued at scale 1 to 5 to verify the instrument of questionnaire, the value of field experts validity obtained is $r=.92$. A total of 79 questionnaire items have been developed to assess the performance of attributes namely psychological characteristics based on nine sub attributes. The sub attributes are anxiety control, mental preparation, team orientation, concentration, self-confidence, motivation, coping with adversity, peaking under pressure and coachability. Based on the factor analysis results, only 50 items were accepted as valid psychological characteristics questionnaire items. Cronbach's alpha analysis of questionnaire items obtained high reliability total value of $\alpha=.86$ and the internal consistency coefficient for each sub attributes are anxiety control $(\alpha=.83)$, mental preparation $(\alpha=.82)$, team orientation $(\alpha=.84)$, concentration $(\alpha=.83)$, self-confidence $(\alpha=.84)$, motivation $(\alpha=.82)$, coping with adversity $(\alpha=.87)$, peaking under pressure $(\alpha=.86)$ and coachability $(\alpha=.81)$. Table 2,3 and 4 shows the results of factor analysis.

Table 2. Bartlett's dan Kaiser-Meyer-Olkin (KMO) Test Results

\begin{tabular}{lrr}
\hline Kaiser-Meyer-Olkin Measure of Sampling Adequacy. & & .630 \\
& Approx. Chi-Square & 7545.599 \\
Bartlett's Test of Sphericity & Df & 3081 \\
& Sig. & .000 \\
\hline
\end{tabular}

Kaiser's criterion technique was used to determine the number of components. Components with only one or more eigenvalue were selected in this analysis. There are 23 analysis components with more than one eigenvalue. Finding in Table 2 shows the results of all 79 attribute analysis components on psychological characteristics explained 63.0 per cent variance. The matrix component shows loading in each line expressed that each questionnaire item's correlation with sub attributes comprising anxiety control, mental preparation, team orientation, concentration, self-confidence, motivation, coping with adversity, peaking under pressure and coachability. 
INTERNATIONAL JOURNAL OF ACADEMIC RESEARCH IN BUSINESS AND SOCIAL SCIENCES Vol. 9, No. 11, November, 2019, E-ISSN: 2222-6990 @ 2019 HRMARS

Table 3. Total Variance Explained

\begin{tabular}{cccc}
\hline Component & \multicolumn{3}{c}{ Rotation Sums of Squared Loadings } \\
\cline { 2 - 4 } & Total & \% of Variance & Cumulative \% \\
\hline 1 & 10.262 & 12.990 & 12.990 \\
2 & 6.917 & 8.756 & 21.746 \\
3 & 5.409 & 6.847 & 28.593 \\
4 & 4.131 & 5.229 & 33.822 \\
5 & 3.206 & 4.058 & 37.879 \\
6 & 3.121 & 3.951 & 41.830 \\
7 & 3.079 & 3.897 & 45.727 \\
8 & 3.060 & 3.873 & 49.601 \\
9 & 3.050 & 3.860 & 53.461 \\
\hline
\end{tabular}

Extraction Method: Principal Component Analysis.

To maintain all the nine components for the next analysis, the researchers used the varimax rotation method to minimize the number of questionnaire items which has high correlation on every factor. According to Tabachnick \& Fidell (2007), results based on orthogonal rotation is more easy to be translated and reported. Table 3 shows the result of nine components rotation using the varimax rotation method. The result shows the first component explained 12.99 per cent of variance, the second component explained 8.76 per cent of variance, the third component explained 6.85 per cent of variance, the fourth component explained 5.23 per cent of variance, the fifth component explained 4.06 per cent of variance, the sixth component explained 3.95 per cent of variance, the seventh component explained 3.90 per cent of variance, the eighth component explained 3.87 per cent of variance and the ninth component explained 3.86 per cent of variance. Total amount of variance available which could be explained by all nine components was 53.46 per cent variance and the figure remained after rotation.

Table 4 shows loading factor more than $r=.50$ for nine component of psychological characteristics questionnaire. The high matric correlation coefficient value of a test on a measured factor indicated close relation with the factor (Tabachnick \& Fidell, 2007). Based on the Principal Component Analysis, only 50 items showed high communality score from overall 79 questionnaire items. Column one represented questionnaire items of sub attributes on anxiety control, the second represented mental preparation, the third represented team orientation, the fourth represented concentration, the fifth represented self-confidence, the sixth represented motivation, the seventh represented coping with adversity, the eighth represented peaking under pressure and the ninth represented coachability. According to Pallant (2010), based on this significant results $(r=.50), 50$ items in this analysis are considered valid for attribute psychological characteristics questionnaire in this study. 
INTERNATIONAL JOURNAL OF ACADEMIC RESEARCH IN BUSINESS AND SOCIAL SCIENCES Vol. 9, No. 11, November, 2019, E-ISSN: 2222-6990 @ 2019 HRMARS

Table 4. Construct Validity for Rotated Component Matrix Component

\begin{tabular}{|c|c|c|c|c|c|c|c|c|c|}
\hline \multirow[t]{2}{*}{ Item } & \multicolumn{9}{|c|}{ Component } \\
\hline & 1 & 2 & 3 & 4 & 5 & 6 & 7 & 8 & 9 \\
\hline S19 & .814 & & & & & & & & \\
\hline S17 & .780 & & & & & & & & \\
\hline S18 & .780 & & & & & & & & \\
\hline S58 & .708 & & & & & & & & \\
\hline S22 & .697 & & & & & & & & \\
\hline S74 & .675 & & & & & & & & \\
\hline S56 & .673 & & & & & & & & \\
\hline S27 & .659 & & & & & & & & \\
\hline S4 & .658 & & & & & & & & \\
\hline S3 & .650 & & & & & & & & \\
\hline S35 & .644 & & & & & & & & \\
\hline S40 & .639 & & & & & & & & \\
\hline S44 & .613 & & & & & & & & \\
\hline S59 & .573 & & & & & & & & \\
\hline S60 & .556 & & & & & & & & \\
\hline S16 & .526 & & & & & & & & \\
\hline \multicolumn{10}{|l|}{ S43 } \\
\hline \multicolumn{10}{|l|}{ S57 } \\
\hline \multicolumn{10}{|l|}{ S78 } \\
\hline \multicolumn{10}{|l|}{ S55 } \\
\hline \multicolumn{10}{|l|}{ S46 } \\
\hline \multicolumn{10}{|l|}{ S47 } \\
\hline \multicolumn{10}{|l|}{ S26 } \\
\hline S33 & & .649 & & & & & & & \\
\hline S45 & & .610 & & & & & & & \\
\hline S32 & & .588 & & & & & & & \\
\hline S52 & & .586 & & & & & & & \\
\hline S42 & & .580 & & & & & & & \\
\hline S48 & & .526 & & & & & & & \\
\hline \multicolumn{10}{|l|}{ S53 } \\
\hline \multicolumn{10}{|l|}{ S51 } \\
\hline \multicolumn{10}{|l|}{ S30 } \\
\hline \multicolumn{10}{|l|}{ S29 } \\
\hline \multicolumn{10}{|l|}{ S37 } \\
\hline \multicolumn{10}{|l|}{ S10 } \\
\hline \multicolumn{10}{|l|}{ S54 } \\
\hline \multicolumn{10}{|l|}{ S39 } \\
\hline \multicolumn{10}{|l|}{ S34 } \\
\hline S2 & & & & & & & & & \\
\hline
\end{tabular}


INTERNATIONAL JOURNAL OF ACADEMIC RESEARCH IN BUSINESS AND SOCIAL SCIENCES Vol. 9, No. 11, November, 2019, E-ISSN: 2222-6990 @ 2019 HRMARS

S36

S31

S25

$\mathrm{S} 28$

S23

S24

S21

.778

S77

.759

S64

.646

S8

.616

$\mathrm{S} 13$

.579

S65

.721

S9

.681

S76

.624

S20

.617

S62

.504

S11

S6

S67

S63

.668

S7

.542

S1

.536

S41

.507

S49

S50

S12

S14

.826

$\mathrm{S} 70$

S38

.773

$\mathrm{S} 73$

.513

S69

S79

S66

S61

671

S5

.583

S15

.518

S71

.500

S68

.833

$\mathrm{S} 72$

S75

Extraction Method: Principal Component Analysis.

Rotation Method: Varimax with Kaiser Normalization. 
a. Rotation converged in 11 iterations.

\section{Discussion}

Factor analysis is the most suitable statistical analysis to obtain the construct validity of the psychological characteristics questionnaire. According to Noah (2005), with factor analysis, the appropriate number of items to create certain attributes can be determined and identified. Factor analysis was conducted by following three main steps; firstly, assessment of the suitability of the data for factor analysis, secondly, factor extraction and lastly, factor rotation and interpretation (Pallant, 2010). Out of 79, a total of 50 questionnaire items found has high validity and reliability to measure the psychological characteristics in Malaysian male talented football players aged 13 to 14 years old.

\section{Conclusion}

Recent research has established the validity and reliability of the psychological characteristics questionnaire, showing that it can be used to assess psychological characteristics among Malaysian male talented football players aged 13 to 14 years old. This questionnaire also helps football coaches and talent scouts to improve the diagnostics of psychological characteristics as well as in embedding psychological diagnostics and interventions in the talent development process.

Like in other studies, this particular study has its own limitations. This study has only concentrated on self-assessed psychological characteristics by talented football players themselves. Thus, further research should consider combination of evaluation via internal (players' self-assessment) and external (from the coach) feedbacks in order to a better understanding of psychological characteristics that influence performance. The player can assess his own psychological performance together with the coach to assess what lessons need to be learned. It is important for a coach be able to analyses the players' psychological performances so that he can emphasis on those characteristics that have been well mastered.

\section{Corresponding Authors}

Khairul Sham Hanapiah

PhD Candidate, Sultan Idris Education University, Faculty of Sports Science and Coaching, 35900

Tanjong Malim, Perak, Malaysia.

Email: khairulsham@yahoo.com

\section{References}

Dohme, L. C., Backhouse, S., Piggott, D., \& Morgan, G. (2017). Categorising and defining popular psychological terms used within the youth athlete talent development literature: A systematic review. International Review of Sport and Exercise Psychology, 10(1), 134-163.

Durand-Bush, N., \& Salmela, J. H. (2002). The development and maintenance of expert athletic performance: Perceptions of world and olympic champions. Journal of Applied Sport Psychology, 14(3), 154-171.

Elbe, A. M., \& Wikman, J. M. (2017). Psychological factors in developing high performance 
INTERNATIONAL JOURNAL OF ACADEMIC RESEARCH IN BUSINESS AND SOCIAL SCIENCES Vol. 9, No. 11, November, 2019, E-ISSN: 2222-6990 @ 2019 HRMARS

athletes. In J. Baker, S. Cobley, J. Schorer, \& N. Wattie (Eds.), Routledge handbook of talent identification and development in sport (pp. 169-180). New York, NY: Taylor \& Francis Group.

Hashim, A. (2014). Panduan analisis data secara efisien: Panduan lengkap berajah untuk menganalisis data. Bandar Baru Bangi: Dubook Press Sdn Bhd.

Jones, J. W., Neuman, G., Altmann, R., \& Dreschler, B. (2001). Development of the sports performance inventory: A psychological measure of athletic potential. Journal of Business and Psychology, 15(3), 491-503.

Kementerian Belia dan Sukan Malaysia. (2014). Pelan pembangunan bola sepak negara fasa 1 : 2014-2020. Putrajaya: Kementerian Belia dan Sukan Malaysia.

Konting, M. M. (2009). Kaedah Penyelidikan Pendidikan. Ampang: Dawama Sdn. Bhd.

MacNamara, A., \& Collins, D. (2012). Do mental skills make champions? Examining the discriminant function of the psychological characteristics of developing excellence questionnaire. Journal of Sports Sciences, 31(7), 736-744.

MacNamara, A., \& Collins, D. (2015). Profiling, exploiting, and countering psychological characteristics in talent identification and development. The Sport Psychologist, 29(1), 7381.

Mahoney, M. J., Gabriel, T. J., \& Perkins, T. S. (1987). Psychological skills and exceptional athletic performance. The Sport Psychologist, 1(3), 181-199.

McCarthy, P. J., Jones, M. V., Harwood, C. G., \& Olivier, S. (2010). What do young athletes implicitly understand about psychological skills? Journal of Clinical Sport Psychology, 4(2), 158-172.

Morris, T. (2000). Psychological characteristics and talent identification in soccer. Journal of Sports Sciences, 18(9), 715-726.

Musculus, L., \& Lobinger, B. H. (2018). Psychological characteristics in talented soccer playersRecommendations on how to improve coaches ' assessment. Frontiers in Psychology, 9(41), 1-6.

Noah, S. M. (2005). Pengujian dan penilaian dalam kaunseling: Teori dan aplikasi. Serdang: Penerbit Universiti Putra Malaysia.

Noah, S. M., \& Ahmad, J. (2005). Pembinaan modul: Bagaimana membina modul latihan dan modul akademik. Serdang: Penerbit Universiti Putra Malaysia.

Pallant, J. (2010). SPSS survival manual: A step by step guide to data analysis using SPSS (4th ed.). New York, NY: McGraw-Hill Companies.

Rees, T., Hardy, L., Gullich, A., Abernethy, B., Cote, J., Woodman, T., Montgomery, H., Laing, S., \& Warr, C. (2016). The Great British medalists project: A review of current knowledge on the development of the world's best sporting talent. Sports Medicine, 46(8), 1041-1058.

Reilly, T., Williams, A. M., \& Richardson, D. (2003). Identifying talented players. In T. Reilly \& A. M. Williams (Eds.), Science and soccer (2nd ed., pp. 307-326). London: Routledge.

Smith, R. E., Schutz, R. W., Smoll, F. L., \& Ptacek, J. T. (1995). Development and validation of a multidimensional measure of sport-specific psychological skills: The athletic coping skills inventory-28. Journal of Sport \& Exercise Psychology, 17(4), 379-398.

Tabachnick, B. G., \& Fidell, L. S. (2007). Using multivariate statistics (4th ed.). Bosrom: Pearson 
INTERNATIONAL JOURNAL OF ACADEMIC RESEARCH IN BUSINESS AND SOCIAL SCIENCES

Vol. 9, No. 11, November, 2019, E-ISSN: 2222-6990 @ 2019 HRMARS

Educational, Inc.

Williams, A. M., \& Reilly, T. (2000). Talent identification and development in soccer. Journal of Sports Sciences, 18(9), 657-667. 